\title{
Cocoa and Dark Chocolate Polyphenols: From Biology to Clinical Applications
}

\author{
Thea Magrone ${ }^{1 *}$, Matteo Antonio Russo ${ }^{2}$ and Emilio Jirillo ${ }^{1,3}$ \\ ${ }^{1}$ Department of Basic Medical Sciences, Neuroscience and Sensory Organs, University of Bari, Bari, Italy, ${ }^{2}$ MEBIC \\ Consortium, San Raffaele Open University of Rome and IRCCS San Raffaele Pisana of Rome, Rome, Italy, ${ }^{3}$ Fondazione San \\ Raffaele, Ceglie Messapica, Italy
}

OPEN ACCESS

Edited by:

Lorraine M. Sordillo,

Michigan State University,

United States

Reviewed by:

Margarida Castell,

University of Barcelona, Spain

Nicolò Merendino,

Università degli Studi della

Tuscia, Italy

${ }^{*}$ Correspondence:

Thea Magrone

thea.magrone@gmail.com,

thea.magrone@uniba.it

Specialty section:

This article was submitted to Nutritional Immunology,

a section of the journal

Frontiers in Immunology

Received: 04 April 2017

Accepted: 24 May 2017

Published: 09 June 2017

Citation:

Magrone T, Russo MA and Jirillo E (2017) Cocoa and Dark Chocolate

Polyphenols: From Biology to

Clinical Applications.

Front. Immunol. 8:677.

doi: 10.3389/fimmu.2017.00677
It is well known that cocoa and dark chocolate possess polyphenols as major constituents whose dietary consumption has been associated to beneficial effects. In fact, cocoa and dark chocolate polyphenols exert antioxidant and anti-inflammatory activities switching on some important signaling pathways such as toll-like receptor $4 /$ nuclear factor $\mathrm{\kappa B} /$ signal transducer and activator of transcription. In particular, cocoa polyphenols induce release of nitric oxide (NO) through activation of endothelial NO synthase which, in turn, accounts for vasodilation and cardioprotective effects. In the light of the above described properties, a number of clinical trials based on the consumption of cocoa and dark chocolate have been conducted in healthy subjects as well as in different categories of patients, such as those affected by cardiovascular, neurological, intestinal, and metabolic pathologies. Even if data are not always concordant, modifications of biomarkers of disease are frequently associated to improvement of clinical manifestations. Quite interestingly, following cocoa and dark chocolate ingestion, cocoa polyphenols also modulate intestinal microbiota, thus leading to the growth of bacteria that trigger a tolerogenic anti-inflammatory pathway in the host. Finally, many evidences encourage the consumption of cocoa and dark chocolate by aged people for the recovery of the neurovascular unit.

Keywords: anti-inflammatory activity, cocoa, dark chocolate, flavanols, nitric oxide, polyphenols, reactive oxygen species, transcription factors

\section{INTRODUCTION}

Polyphenols represent a class of natural products that are very spread in the plant kingdom. Mostly, fruits, vegetables, and cereals are considered as major sources of dietary polyphenols, which human beings assume with food. In this context, Mediterranean diet (MED) represents an healthy nutritional regimen based on the consumption of extra virgin olive oil, fruits, vegetables, cereals, legumes, nuts, and seeds plus moderate intake of red wine $(1,2)$. It has been reported that MED is highly protective against chronic low-grade inflammation, and, in the case of atherosclerosis, stabilizes atheromatous plaques (3). Another study has emphasized the important role played by resveratrol, a non-flavonoid compound contained in red wine, to induce formation of sirtuins (Sirt) which, in turn, exert potent anti-aging effects (4). The MOLI-sani project has documented that in a large prospective cohort study of 24,325 Italian people MED reduced levels of glucose, lipids, C reactive protein (CRP), blood pressure (BP), and 10-year cardiovascular risk (5). Quite interestingly, Morabito and associates (6) have demonstrated that polyphenols contained in fruit juices prevent the post-prandial metabolic stress in humans as well as inflammatory disease outcome. 
Taken together, all these are general consideration on dietary polyphenols effects and for more details on their chemical structure and functions, readers are referred to Ref. $(7,8)$.

With special reference to cocoa, polyphenols are constituents of the beans and their derivatives from the Theobroma cacao tree. Cocoa liquor is the paste derived from cocoa beans, the so-called nibs, and it is composed by non-fat cocoa solids and cocoa butter (9). Instead, cocoa powder is obtained by getting rid of some of the cocoa butter from the liquor. Finally, chocolate results from the combination of cocoa liquor with cocoa butter and sugar.

With regard to lipids, cocoa butter contains both monounsaturated and saturated fatty acids (FAs) (10). Oleic acid is the major monounsaturated FA that is present in similar amounts to those contained in the olive oil (10). Conversely, palmitic and stearic acids represent the main saturated FAs. However, stearic acid has been found to be anti-atherogenic, also accounting for one-third of the lipids contained in cocoa butter (11).

Fibers are present in cocoa beans, and their consumption has been shown to improve the low density lipoprotein (LDL):high density lipoprotein (HDL) ratio (12), also reducing risk of type 2 diabetes (13).

Among minerals, magnesium, copper, potassium, and iron are present in cocoa and chocolate in significant amounts (14). Magnesium, copper, and potassium exert a cardio protective role (15-17), while iron, mainly present in dark chocolate, contributes to the $25 \%$ of the U.S. recommended dietary allowance for middle-aged man, thus preventing anemia outcome (18).

Finally, with regard to polyphenol composition, catechins, anthocyanins, and proanthocyanidins are the most abundant class of compounds contained in cocoa powder (19). In particular, flavanols are presented as monomers, e.g., monomers (+) - and $(-)-$ isomers of catechin and epicatechin (epi), and, in addition their derivatives are build-up of epi subunit polymers (proanthocyanidins) (19-21). Minor components are represented by phenolic acids, flavonols, and their glycoside, some stilbenes, simple phenol, and isocoumarin (22-24). Among anthocyanins, cyanidins-3- $\alpha$-L-arabinoside and cyanidin-3- $\beta$-D-galactoside are the most represented compounds (18). (-)- epi accounts for the $35 \%$ of the total phenolic content, while $(+)-$ catechin, $(+)-$ epigallocatechin and gallocatechin are minor constituents. Procyanidins are present as dimers, trimers, and oligomers of flavan-3, 4 -diols, linked by $4 \rightarrow 8$ or $4 \rightarrow 6$ bounds $(20,25,26)$.

As far as bioavailability of cocoa is concerned, monomeric and polymeric flavanols are rapidly absorbed in the small intestine upon ingestion with a maximal plasma concentration after $2 \mathrm{~h}$ from intake (27). Elimination of flavanols is completed after $6 \mathrm{~h}$ from ingestion (28). However, absorption not only depends on flavanol chemistry but also on their structural isomerism and stereoisomerism (29). Also, the range of polymerization seems to determine their bioavailability (30). Once absorbed under form of monomers, flavanols are transformed into metabolites detectable in plasma and urine, such as (-) - epi as sulfate, glucuronides, or methyl conjugated forms $(31,32)$. On the other hand, polymers and monomers of unabsorbed flavanols undergo colonic microbiota catabolism, and valero lactones and valeric acids represent the so-called first-step microbiota-derived catabolites $(33,34)$. Instead, a number of phenolic acids constitute intermediate and last-step catabolites $(33,35-37)$. Of note, a part of unabsorbed flavanols is excreted into the feces $(33,38,39)$. In this framework, it is worthwhile emphasizing that microbiota-derived metabolites of ingested polyphenols in view of their healthy effects are object of intensive investigation $(40,41)$. For instance, with special reference to consumers of cocoa polyphenols, a comparison between regular consumers of chocolate and low consumers has clearly shown a significant difference in terms of metabolite profiles (42).

This review will illustrate the major effects of cocoa and dark chocolate consumption in health and disease and possible cellular and molecular mechanisms of action involved also in relation to putative therapeutic implications.

\section{EFFECTS OF COCOA AND DARK CHOCOLATE ON THE CARDIOVASCULAR SYSTEM}

The cardioprotective effects exerted by polyphenols have been published long ago $(43,44)$. Since then, a series of studies supported the protective effects of cocoa and chocolate intake on the cardiovascular system. First of all, there is robust evidence that consumption of flavanol-rich cocoa leads to beneficial effects in healthy individuals. A study has documented that vasodilation was the main effect observed as a consequence of nitric oxide (NO) release following cocoa ingestion (45). In this connection, improvement of endothelial function was higher in older ( $>50$ years) than in younger ( $<50$ years) healthy individuals, as assessed by flow-mediated dilation (FMD) measurement (46). In this context, ex vivo flavanol-induced relaxation of preconstricted rabbit aortic rings, as well as in vivo increase in FMD were abrogated by inhibition of NO synthase, thus supporting the role of $\mathrm{NO}$ in the amelioration of endothelial function (21).

In an acute study, the effects of dark chocolate and white chocolate were evaluated in healthy participants monitoring variations of FMD and BP (47). Actually, dark chocolate was more effective than white chocolate in lowering the above mentioned parameters. In the second phase of the study, sugar-free but not sugared cocoa consumption led to a significant reduction of both systolic and diastolic BP in comparison with placebo (48). In similar trials, the effects of consumption of solid dark chocolate on endothelial function of healthy individuals were determined (49). A significant increase in FMD was observed in high-flavonoid intakers of dark chocolate ( $46 \mathrm{~g}$ ) when compared to low flavonoid intakers once a day for 2 weeks. Shiina et al. (50) reported in healthy individuals an increase of coronary flow velocity reserve following consumption of $45 \mathrm{~g}$ of flavonoid-rich dark chocolate in comparison to flavonoid-free white chocolate. All these evidences are confirmed by studies conducted in Kuna islanders who commonly ingest higher amounts of cocoa than mainlanders $(51,52)$. In fact, in the former urinary flavanol metabolites were more elevated than in the latter, and this evidence correlates with low rate of cardiovascular disease (CVD), diabetes, and cancer in islanders.

On the other hand, in subjects at risk for CVD, consumption of cocoa led to results of clinical value, such as increase in nitrosylated and nitrosated species and FMD (53). Same results were 
obtained in smokers who consumed high flavanol cocoa beverages for 7 days (54). FMD increase was maintained on each day after a washout of 1 week. Also in diabetics, chronic consumption of cocoa three times a day for 30 days, containing $321 \mathrm{mg}$ of flavanols, led to higher increase in FMD in comparison to the lowflavanol cocoa group (55). Conflicting results have been obtained in patients with coronary artery disease (CAD). For instance, in a study involving $40 \mathrm{CAD}$ patients who consumed a chocolate bar and cocoa beverage, containing $444 \mathrm{mg}$ of flavanols for 6 weeks, no significant differences were seen in terms of endothelial function measurement and high-sensitivity CRP, oxidized LDL, lipids, glucose, and insulin determination in comparison to placebotreated patients (56). Conversely, in another research, 16 CAD patients were divided into 2 groups, one receiving high flavanol cocoa $(375 \mathrm{mg}$ ) and another one consuming low flavanol cocoa (9 mg) 2 times a day for 30 days, randomly (57). More significant results were observed in the high flavanol group in comparison to the low flavanol group in terms of increase in both FMD and mobilization of circulating angiogenic cells and decrease in BP. Furthermore, other two studies have clearly demonstrated the effects of daily chocolate consumption on coronary circulation. In heart transplanted individuals, intake of $40 \mathrm{~g}$ of dark chocolate led to increase in coronary artery diameters and endotheliumdependent coronary vasomotion $2 \mathrm{~h}$ after intake of flavonoid-rich dark chocolate with a significant decrease in platelet aggregation (58). Parallely, increase in serum epi was recorded.

With regard to the mechanisms of action of $\mathrm{NO}$ on endothelium function, there is evidence that it causes arterial vasodilation in healthy subjects, while in individuals at risk for cardiac disease NO response is decreased while oxidative stress is increased (59-61). Furthermore, NO exerts anti-inflammatory activity in situ by decreasing leukocyte recruitment and platelet aggregation (62). In this framework, our own studies have clearly demonstrated that human healthy peripheral monocytes are great producers of $\mathrm{NO}$ when in vitro stimulated with red wine polyphenols (63). Then, in addition to endothelial cells, which are another source of $\mathrm{NO}$, also monocytes contribute to the $\mathrm{NO}$-mediated vasodilation and cardioprotection.

Taken together, these evidences clarify why polyphenols, even including those from cocoa and dark chocolate, are able to improve endothelial function in health and disease via NO release.

With regard to the mechanisms of NO release, all polyphenols regardless of their sources are able to activate endothelial NO synthase (eNOS), thus leading to NO generation (64). The administration of pure (-) - epi seems to reproduce the effects of cocoa-induced synthesis of NO on human coronary artery endothelial cells through eNOS activation via phosphatidylinositide 3-kinases/protein kinase $\mathrm{B}$, also known as AKT/protein kinase A and $\mathrm{Ca}^{2+}$-calmodulin (CaM)/CaM K II pathway (64). Moreover, by inhibiting phospholipase $\mathrm{C}$, evidence has been provided for the existence of a putative epi receptor on the cellular plasmalemma (64).

Once released, NO is able to activate the soluble guanylate cyclase in the smooth muscle cells and platelets with increase of cyclic guanosine monophosphate (cGMP) $(65,66)$. The subsequent inhibition of calcium flux and decrease of cytosolic calcium concentration give rise to smooth muscle cell relaxation and platelet aggregation inhibition (see also next paragraphs) $(65,66)$. Furthermore, cGMP is able to increase cyclic adenosine monophosphate (cAMP), which, in turn, activates prostacyclin (65-67). Quite interestingly, prostacyclin acts as a vasodilator in synergy with NO, thus contributing to protection from thrombosis. Furthermore, the anti-inflammatory and vasoprotective properties of prostacyclin are enhanced by its capacity to decrease plasma leukotrienes $(68,69)$.

Some of the major vasoprotective effects of cocoa and dark chocolate are illustrated in Figure 1.

Finally, NADPH oxidase seems to be another target of NO activity. In fact, cocoa polyphenols reduce levels of NADPH oxidase, which generates $\mathrm{O}_{2}^{-}$that, in turn, scavenges NO. Therefore, its inhibition increases levels of $\mathrm{NO}(70,71)$.

Another important target of polyphenol-rich cocoa is represented by platelets. First of all, platelets can per se release NO under influence of flavanols (72), thus contributing to vasodilation. Cocoa-mediated inhibition of platelet aggregation has been shown to depend on the decrease of thromboxan (TX) A2 synthesis

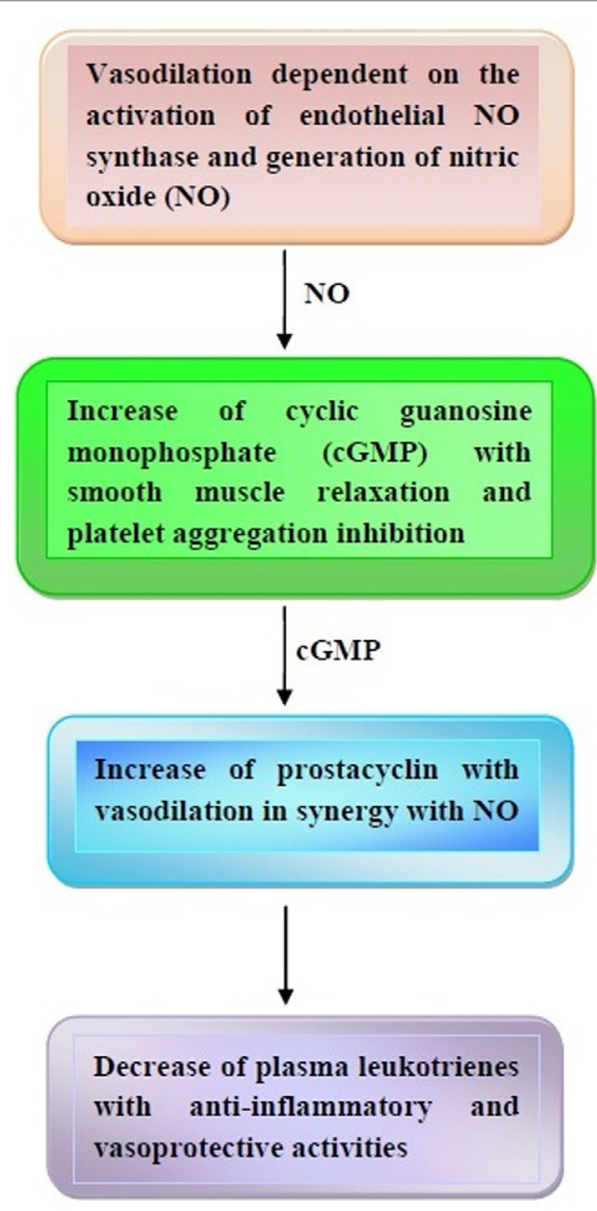

FIGURE 1 | Major effects of cocoa and dark chocolate on the cardiovascular system. In response to cocoa and dark chocolate ingestion, a cascade of events takes place based on the nitric oxide (NO) and cyclic guanosine monophosphate (cGMP)-induced vasodilation and prostacyclin-mediated anti-inflammatory effects. Other details are contained in the text. 
and antagonism at TXA2 receptors (73-75). Furthermore, other possible mechanisms of action are represented by the inhibition of platelet-leukocyte interaction since cocoa flavanols are able to inhibit CD62P expression on activated platelets (76-78). Of note, CD62P binds P-selectin glycoprotein ligand-1 on leukocytes, thus mediating the platelet-leukocyte interaction.

A series of studies have demonstrated the cocoa's platelet inhibitory effects in healthy individuals and in heart transplant patients (79-81) who had consumed cocoa or dark chocolate. Taking into account that platelet activation greatly contributes to the inflammation and thrombosis in the progression of CVD, their inhibition by polyphenol-rich diets, even including consumption of cocoa and dark chocolate, is of clinical relevance.

The cocoa-mediated decrease of BP can be ascribed to several mechanisms. Increase in NO may explain the anti-hypertensive effects of cocoa (82). In addition, there is also evidence that flavanols and flavonol are able to in vitro inhibit angiotensin-converting enzyme (ACE) activity $(83,84)$. ACE, in turn, acts on the renin-angiotensin system, cleaving angiotensin I into angiotensin II with release of vasopressin or aldosterone and anti-diuretic hormone and increase in sodium and water retention. ACE also inhibits bradykinin and kallidin, which act as vasodilators (85).

In terms of effects of cocoa on serum lipid profile, a number of studies have clearly demonstrated that consumption of cocoa leads to increase in HDL while lowering $\operatorname{LDL}(86,87)$. The same holds true also in the case of ingestion of high-polyphenol chocolate (88). Basically, same results were reported in individuals fed cocoa beverages containing only cocoa powder. Furthermore, a meta-analysis study confirmed the ability of cocoa to reduce LDL cholesterol and total cholesterol in subjects at high cardiovascular risk $(89,90)$. Also, inhibition of LDL oxidation is another effect of both cocoa and dark chocolate consumption (89-92). Conversely, other studies failed to demonstrate significant differences in serum lipids between consumers of high-flavonoid chocolate and consumers of low-flavonoid chocolate $(49,93)$. Similarly, in other three studies, no effects of cocoa beverages on serum lipids were observed $(94,95)$.

\section{COCOA AND DARK CHOCOLATE EFFECTS ON THE CENTRAL NERVOUS SYSTEM (CNS) AND BEHAVIOR}

The beneficial effects of polyphenols on the CNS have extensively been described in human and animal studies. The majority of research has been conducted with polyphenols derived from soy, berries, wine, tea, and curcuma and much less from cocoa and chocolate (96). Also, flavonoids extracted from Ginkgo biloba have been reported to retard memory loss, dementia, and Alzheimer's disease $(\mathrm{AD})$ progression. However, data are still controversial $(97,98)$. In a series of researches, the anti-inflammatory activity exerted by polyphenols on the CNS has been documented. Curcumin extracted from Curcuma longa root was able to reduce the production of tumor necrosis factor (TNF)- $\alpha$, interleukin (IL)-6, and reactive oxygen species (ROS) from primary astrocytes in vitro stimulated with 1-methyl-4-phenylpiridinium ion (MPP+) (99). Moreover, curcumin increased levels of IL-10 and glutathione. Curcumin also decreased levels of toll-like receptor (TLR)-4, as well as of NF- $\mathrm{BB}$, interferon regulatory factor 3, MyD88, and TIR-domain-containing adapter-inducing interferon $-\beta$ otherwise enhanced by MPP+ (100). Similarly, epi and resveratrol have been found to exert neuroprotective activity modulating TLR-4/NF- $\mathrm{kB} /$ signal transducer and activator of transcription (STAT) signaling pathways (100).

Others have reported that polyphenols can interact with some signaling pathways, such as mitogen-activated protein and phosphoinositide-3-kinase (PI3-kinase)/AKT, thus leading to gene expression and protein synthesis for long-term potentiation and long-term memory occurrence (101). Flavonoids modulate transcription factors via protein kinase inhibition (102), while inducing the expression of brain-derived neurotrophic factor (BDNF). This factor contributes to neurogenesis, synaptic growth, and neuron survival in certain learning and memory brain regions, such as the hippocampus and subventricular areas $(103,104)$. Another mechanism is based on the generation of NO that leads to vasodilation and increased cerebral blood flow and blood perfusion in the context of the CNS as well as of the peripheral nervous system $(105,106)$. Such an increased blood flow is able to supply oxygen and glucose to neurons, also getting rid of waste metabolites in the brain and sensory organs $(107,108)$ while stimulating angiogenesis in the hippocampus (109). The effects of cocoa flavanols on the brain are represented in Figure 2.

Different cocoa flavonoid effects on Parkinson's disease (PD) have been reported. In PD, death of neurons in substantia nigra depends on the generation of 5-S-cysteinil-dihydrobenzothiazine ROS mediated-effects (110). Quite interestingly, neuronal damage mediated by 5 -S-cys-DA is dramatically mitigated by quercetin, hesperetin, and caffeic acid, which are derivatives of catechin and epi (110). Neuroinflammation is another hallmark of $\mathrm{PD}$ pathogenesis (111). Microglia response plays the major role in the progression of neuronal degeneration and, consumption of cocoa flavonoids, e.g., quercetin, leads to anti-inflammatory effects (112). In particular, quercetin behaves as certain kinase inhibitors that exert anti-inflammatory effects on glial cells (112), likely preventing excitotoxic death in neurons (113). In relevance to the above cited anti-inflammatory effects, evidence has been provided that fermented grape marc (FGM) polyphenols have the capacity to reduce in vitro release of granzyme $\mathrm{B}$ from healthy peripheral human cytotoxic T cells, thus lowering their neurotoxic potential (114). By analogy, cocoa polyphenols may exert similar neuroprotective activity.

Alzheimer's disease is characterized by an increased production of amyloid (A) $\beta$ oligomers, which activate microglia with release of inflammatory mediators and neuronal death (115). In an in vitro model of human $\mathrm{AD}$, cocoa polyphenolic extracts have been shown to exert not only antioxidant effects but also to afford neuroprotection (116). This last effect has been attributed to the activation of BDNF survival pathway either on $A \beta$ plaque-treated cells or on $A \beta$ oligomer-treated cells, thus, ultimately, leading to reduction of neurite dystrophy. Resveratrol, a non-flavonoid component of polyphenols (117), exhibited neuroprotective effects in AD. In fact, it promoted non-amyloidogenic breakdown of the amyloid precursor proteins and removal of neurotoxic $A \beta$ peptides. It is likely that also cocoa polyphenols may exhibit 


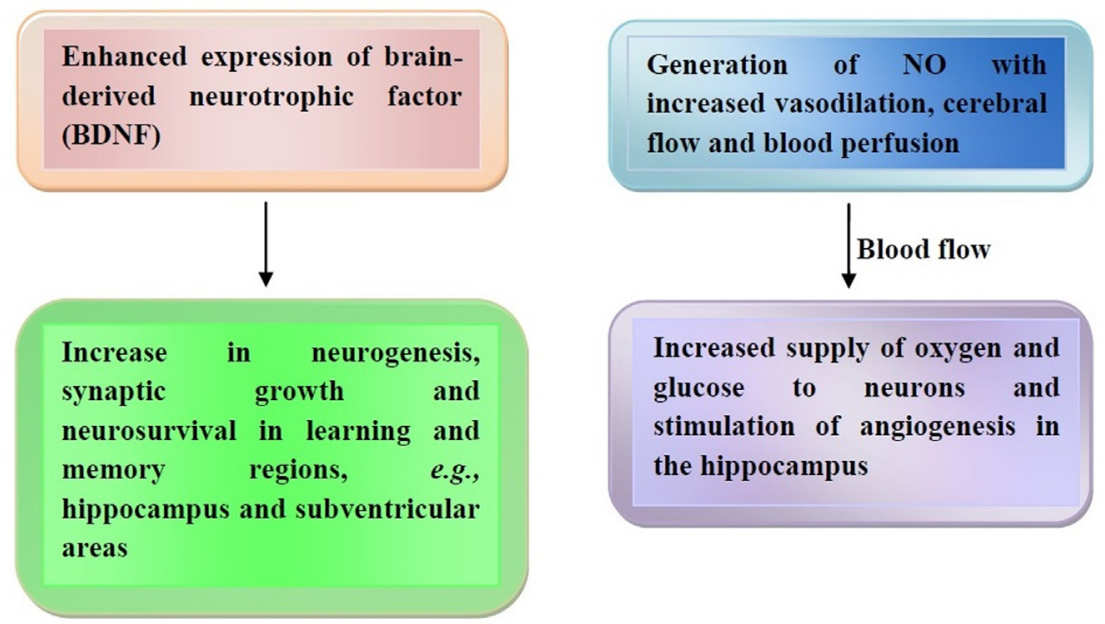

FIGURE 2 | Cocoa flavanol-mediated brain effects. Release of brain-derived neurotrophic factor (BDNF) with increased neurogenesis and neurosurvival (left panel) and nitric oxide (NO)-mediated increase of cerebral blood flow (right panel) are the major effects exerted by cocoa flavanols. Further details are illustrated in the text.

similar activities. Another protective mechanism mediated by cocoa polyphenols is the activation of $\mathrm{NAD}(+)$-dependent histone deacetylase enzymes, termed Sirt (118). In particular, in the course of $\mathrm{AD}$, reduced levels of Sirt1 upregulate NF- $\kappa \mathrm{B}$, which, in turn, trigger inflammation and enhances $A \beta$ toxicity $(119,120)$.

Another experimental study based on the administration of dark chocolate to a non-transgenic AD obese model showed a reduction of hyperglycemia and cholinesterase activity in the hippocampal tissue homogenates and improvement of the cognitive performance (121).

Another neurotrophic effect of cocoa flavonoids is represented by their ability to increase cerebral blood flow in healthy young subjects, as assessed by functional magnetic resonance imaging (FMRI) (122). This effect was observed $3 \mathrm{~h}$ after cocoa consumption. Furthermore, such an increased blood flow to gray matter has been shown to account for angiogenesis as well as growth of new hippocampal neurons involved in the memory processing (110). In this context, evidence has been provided that increase in blood flow in the middle cerebral artery may account for protective effects in the course of dementia and stroke (123).

The effects of cocoa flavonols on PD and AD progression are represented in Table $\mathbf{1}$.

With special reference to the influence on behavior, a series of studies have demonstrated that palatable chocolate consumption is able to improve mood in a more significant manner than that performed by a non-palatable chocolate $(124,125)$. Palatability seems to be related to the chocolate-mediated release of opioids, such as $\beta$-endorphins in the hypothalamus (126), thus producing an analgesic effect (127).

Also, cognitive function has been shown to be improved by cocoa beverages with reduction of mental fatigue (128). However, others did not find any significant change of cognitive tests in comparison to placebo group in healthy old subjects who consumed cocoa-enriched beverages and dark chocolate (129).

Chocolate consumption seems to stimulate different brain areas, especially chemosensory areas, such as insula, prefrontal
TABLE 1 | Beneficial effects of cocoa flavanols on the progression of Parkinson's disease (PD) and Alzheimer's disease (AD).

\begin{tabular}{ll}
\hline PD & AD \\
\hline $\begin{array}{l}\text { Inhibition of 5-S-cysteinil- } \\
\text { dihydrobenzothiazine-mediated } \\
\text { neuronal damage (110) }\end{array}$ & $\begin{array}{l}\text { Activation of brain-derived neurotrophic factor } \\
\text { on amyloid (A) } \beta \text { plaque-treated cells or on A } \beta \\
\text { oligomer-treated cells (116) }\end{array}$ \\
\hline $\begin{array}{l}\text { Anti-inflammatory effect } \\
\text { mediated by quercetin on glial } \\
\text { cells, behaving as certain kinase } \\
\text { inhibitors, thus preventing } \\
\begin{array}{l}\text { excitotoxic death in neurons } \\
(112,113)\end{array}\end{array}$ & $\begin{array}{l}\text { Activation of NAD(+)-dependent histone } \\
\text { deacetylase enzymes known as sirtuins (118) }\end{array}$ \\
\hline & \\
& $\begin{array}{l}\text { Reduction of hyperglycemia and } \\
\text { cholinesterase activity in the hippocampus } \\
\text { with improvement of cognitive functions (121) }\end{array}$
\end{tabular}

region, caudomedial and caudolateral orbitofrontal cortex (130). According to FMIR, a significant taste-related activation in the orbitofrontal and insular cortices was reported (131). Also, chocolate color modulates brain activity with significant reduction in theta activity. This implies reduced levels of attention and higher levels of distraction (132). Finally, the sight of chocolate generated more activation in chocolate cravers than non-cravers in the medial orbitofrontal cortex and ventral striatum (133).

\section{EFFECTS OF COCOA AND DARK CHOCOLATE ON INTESTINAL INFLAMMATION}

Over the past years, plant-derived polyphenols have been experimented in in vitro and in vivo models of intestinal inflammation in view of their anti-inflammatory potential $(134,135)$. Interesting results have been obtained in vitro treating Caco- 2 cells with cocoa polyphenols (134). Such a treatment led to induction of prostaglandin E2 synthesis via cyclooxygenase (COX)-1 effect, 
which may be involved in the maintenance of mucosal integrity. On the other hand, the murine model of dextran sulfate sodium (DSS)-induced colitis has been used for investigating the effects of polyphenol administration. For instance, administration of cocoa FGM-derived polyphenols to DSS-induced colitis mice led to a partial but significant abrogation of intestinal length reduction, while levels of TNF- $\alpha$ and IL- $1 \beta$ significantly dropped in inflamed colon homogenates in comparison to untreated colitis animals (136). Similar results have been documented by Pérez-Berezo and associates (137) in rats with DSS-induced colitis administered with a cocoa-enriched diet. Decrease of colonic cellular infiltrates was paralleled by reduction of serum TNF- $\alpha$ and colon inducible (iNOS) activity. However, despite the reported changes, no clinical improvement was recorded in rats. In a murine model of DSS-induced colitis, Andújar and associates (138) reported that administration of cocoa polyphenols mitigated symptomatology accompanied by reduction of neutrophil infiltration, NO generation, expression of COX-2 and STAT-1 and STAT-3 (138) as well reduction of IL- $1 \beta$, IL- 6 , and TNF- $\alpha$ from peritoneal macrophages (138). These modifications of biomarkers were associated to improvement of colitis. However, no inhibitory effect of NF- $\kappa B$ was detected in the nuclear extract of colon. Conversely, cocoa consumption by healthy volunteers led to a significant reduction of NF- $\mathrm{KB}$ in peripheral blood mononuclear cells (PBMCs), thus suggesting an inhibitory effect on the release of pro-inflammatory cytokines (139).

In the light of these results, addition of polyphenols to enteral nutrition in patients with inflammatory bowel disease may be beneficial in view of their ability to induce phase II antioxidant and detoxifying proteins, thus preventing or improving the inflammatory status (140).

\section{EFFECT OF COCOA AND DARK CHOCOLATE ON OBESITY}

Evidence has been provided that cocoa administration to rats decreased visceral adipose tissue, thus changing the expression of genes, which are involved in the generation of enzymes and molecules for the occurrence of FA synthesis and thermogenesis in liver and white adipose tissue (141). In a study conducted in 12 females, dark chocolate smelling was assessed for evaluating appetite response (142). This led to a satiation response, which inversely correlated with ghrelin levels. Since ghrelin is involved in adiposity induction (143), one can conclude that chocolate may reduce appetite, preventing weight gain. Furthermore, evidence has been provided that flavonoids act on peroxisome proliferatoractivated receptors (PPARs), thus behaving as agonists of PPAR- $\alpha$ and partial agonist of liver X receptor $\alpha$ (144-146). In addition, increased expression of PPAR- $\gamma$, which, in turn, increases expression of adiponectin and glucose transporter 4 , is another mechanism elicited by cocoa flavonoid consumption (147). These events may lead to reduced lipogenesis, induction of lipolysis, and increase in adiponectin secretion. Adiponectin also reduces lipid deposition and insulin resistance, thus mitigating obesity.

These last mechanisms are depicted in Figure 3.

Another important function of cocoa flavanols related to obesity is the delay of LDL oxidation. For example, they decrease

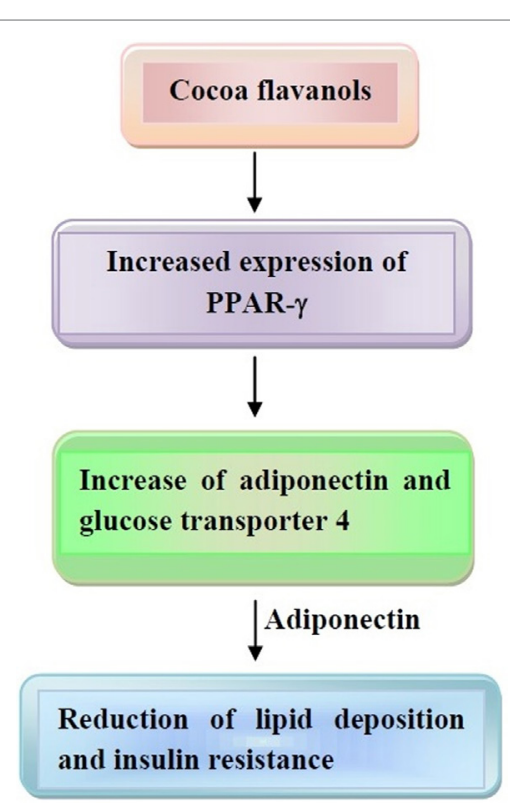

FIGURE 3 | Mechanisms of action of cocoa flavanols on obesity development. Increased expression of peroxisome proliferator-activated receptor (PPAR)- $\gamma$ and adiponectin leads to reduction of lipid deposition and insulin resistance. Other details are present in the text.

F2-isoprostane levels, which represent in vivo markers of lipid peroxidation $(148,149)$. As result of LDL oxidation inhibition, decrease in atherosclerotic lesions in hypercolesterolemic rabbits treated with a diet enriched in cocoa powder for 24 weeks has been documented (150). Conversely, other researchers failed to confirm inhibition of LDL oxidation in rats treated with cocoa polyphenols for 2 weeks (151). In healthy human volunteers, evidence has been provided that cocoa consumption led to decrease of F2-isoprostane and thiobarbituric acid reactive substances, which are biomarkers of LDL oxidation and lipid peroxidation, respectively (152-154). Quite interestingly, in healthy humans, cocoa consumption increased plasma HDL cholesterol $(92,155)$, while decreasing plasma triglycerides (156-158). These results suggest the healthy benefits of cocoa consumption by changing the expression of genes involved in FA catabolism.

\section{EFFECT OF COCOA AND DARK CHOCOLATE ON THE IMMUNE SYSTEM}

Several studies of our group have been conducted on the effects of red wine or FGM-derived polyphenols on the immune cells. In murine models of asthma, FGM-derived polyphenols were able to mitigate symptomatology (159) when orally administered. In human studies, both red wine and FGM-derived polyphenols were able to induce in vitro activation of T regulatory (Treg) cells and release of IL-10, which, in turn, mediates anti-inflammatory activity $(160,161)$. FGM-derived polyphenols were also able to reduce the respiratory burst of healthy neutrophils and monocytes and abrogate basophil as well as rat mast cell degranulation in vitro $(162,163)$. 
With special reference to cocoa flavanols, their in vivo administration to experimental animals has clearly demonstrated changes in the lymphoid organs. In rats, a diet based on $10 \%$ cocoa led to thymocyte differentiation and upregulation of thymic antioxidant defenses (164). Same dietary regimen increased splenic B cell percentage and decreased splenic $T$ helper $(\mathrm{h})$ cell frequency in rats $(165,166)$. In the gut of rats, changes in lymphomonocyte profile and Th cells frequency at Peyer's patches and mesenteric lymph node levels were noted following cocoa administration $(165,166)$.

The in vitro effects of cocoa on cytokine secretion are quite controversial. Increase in TNF- $\alpha$, IL- $1 \beta$, IL-6, and IL-10 from human PBMCs stimulated with flavanol fractions of cocoa have been reported (167). Conversely, following cocoa stimulation reduced production of TNF- $\alpha$, monocyte chemoattractant protein-1, and NO by endotoxin-stimulated macrophages has been documented (168). In the same set of experiments, it was reported that cocoa polyphenols were able to modulate endotoxin activation of granulocytes (168). With special reference to Th cells, a cocoa diet in rats increased IL-4 production (a Th2 cytokine) from splenocytes (169). Secretion of interferon- $\gamma$ from rat splenic Th1 cells was unmodified $(166,170)$, increased (171), or in vitro suppressed by cocoa extracts (172). Of note, cocoa diet did not modify rat IL-10 production $(166,173)$.

A series of experiments with procyanidin C1 using RAW 264.7 macrophages have clarified some important aspects of cocoa-mediated immunomodulation. In this respect, procyanidin C1 significantly enhanced levels of iNOS-mediated NO generation by activated macrophages (174). In addition, it increased the expression of the costimulatory molecules CD80 and CD86, thus potentiating antigen presentation to T cells (175). With regard to signaling pathways, procyanidin $\mathrm{C} 1$ was able to trigger phosphorylation of MAPKs, even including p38 and extracellular signal-regulated kinase as well as of nuclear factor of kappa light polypeptide gene enhancer in B-cells inhibitor- $\alpha$ with subsequent activation of NF- $\mathrm{BB}$. These findings were confirmed by using specific inhibitors of NF- $\mathrm{BB}$ and MAPK, which hampered pro-inflammatory cytokine production in the same experimental model.

Transforming growth factor (TGF)- $\beta 1$ is a pleiotropic cytokine involved in tissue repair and regeneration $(176,177)$. Therefore, the effects of cocoa flavanols on the production of this cytokine were also evaluated in human subjects (178). Results pointed out that in healthy subjects cocoa consumption was able to regulate TGF- $\beta 1$ production with an increase in low producers and a decrease in high producers (178). Of note, low levels of TGF- $\beta 1$ were detected in patients with advanced atherosclerosis (178), while its excessive production has been shown to lead to cardiac fibrosis (179). Therefore, cocoa consumption by individuals with cardiovascular risk leads to modulation of TGF- $\beta 1$ production, thus leading to protective functions.

Cocoa flavanols have been shown to regulate secretion of IL-5. Smaller molecular weight flavanol fractions were able to in vitro enhance IL-5 release by healthy human PBMCs, while larger molecular weight flavanol fraction decreased its release (180). The cocoa-induced increase of IL-5 may be indicative of a switch of the humoral immune response toward secretory $\operatorname{IgA}$ production, thus reducing the risk for caries and periodontal disease (180).

Finally, the effects of cocoa polyphenols on the composition of intestinal microbiota need to be mentioned. According to studies of Tzounis and associates $(181,182)$, Spencer and associates (183), and Massot-Cladera and associates (184), flavanol monomers and dimers are absorbed in the small intestine, while procyanidins are metabolized in the colon by the intestinal microbiota into a variety of phenolic acids, which are also absorbed. All absorbed products are metabolized in the liver and eliminated in the urine, and, partly, in the feces. In a human trial conducted on healthy volunteers, consumption of a high-cocoa flavanol beverage for 4 weeks, containing $494 \mathrm{mg}$ flavanols, significantly increased the growth of Lactobacillus spp. and Bifidobacterium spp. in comparison to a low cocoa flavanol drink (182). Usually, these bacteria are able to maintain an anti-inflammatory status in the bowel with activation of Treg cells and production of IL-10 (185), thus suggesting that cocoa polyphenols may behave as prebiotics and trigger a tolerogenic pathway in the gut.

The effects of cocoa on microbiota are illustrated in Figure 4.

At the end of this section, one should mention the effects of $(-)$ - epi, (+) - catechin, and dimeric flavonols on NF- $\mathrm{KB}$, a transcription factor involved in immune cell activation.

The abovementioned compounds are able to inhibit NF- $\kappa \mathrm{B}$ activation, and, in particular the phorbol mirystate acetate (PMA) DNA binding activity, thus resulting in IL-2 production decrease (185). Inhibition of binding activity is provoked by a blockade of the binding of active NF- $\mathrm{KB}$ to the DNA KB

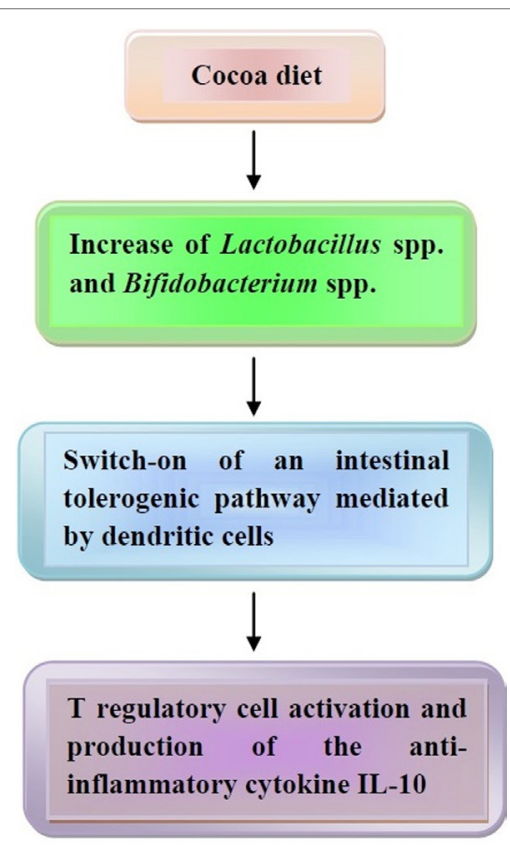

FIGURE 4 | The effects of coca-enriched diet on human microbiota. Cocoa diet modifies the intestinal microbiota, thus leading to a tolerogenic pathway with release of the anti-inflammatory cytokine interleukin (IL)-10. In the text, further details are illustrated. 
motifs. Finally, pretreatment with flavanols leads to decrease of PMA-stimulated intracellular oxidants, which is an early event in NF- $\kappa \mathrm{B}$ triggering.

\section{CONCLUSION}

There is wealth of evidences concerning the relationship between health status and integrity of vascular and neurological functions. As extensively described in the previous sections of this review, cocoa and dark chocolate-mediated induction of NO leads to vasodilation as well as inhibition of COX-2, CRP, and atherogenesis $(186,187)$. In addition, NO acts in concert with BDNF in order to modulate neural progenitor cell growth and synaptic metabolism for appropriateness of cognitive functions (188-190). Quite interestingly, release of NO at the thalamus level contributes to the adequate functioning of the neurovascular unit via increased blood flow and volume in the context of the brain $(191,192)$. Furthermore, polyphenols, even including those from cocoa, exert antioxidant effects, thus increasing neurological functions also preventing age-dependent damage (193). In synthesis, by analogy to other plant-derived polyphenols, cocoa flavanols may exert beneficial effects via activation of eNOS, inhibition of the NADPH oxidase and ROS production, downregulation of NF- $\mathrm{KB}$, and regulation of MAPK and CAMP response element-binding protein pathways (194-197). In aging, especially neurological functions become deteriorated, and NO and aging seem to be interconnected. For instance, alterations of NOS have been detected in aging brain, thus influencing memory $(96,198,199)$.

\section{REFERENCES}

1. Trichopoulou A, Lagiou P. Healthy traditional Mediterranean diet: an expression of culture, history, and lifestyle. Nutr Rev (1997) 55(11 Pt 1):383-9. doi: 10.1111/j.1753-4887.1997.tb01578.x

2. Castro-Quezada I, Román-Viñas B, Serra-Majem L. The Mediterranean diet and nutritional adequacy: a review. Nutrients (2014) 6(1):231-48. doi:10.3390/ nu6010231

3. Casas R, Sacanella E, Estruch R. The immune protective effect of the Mediterranean diet against chronic low-grade inflammatory diseases. Endocr Metab Immune Disord Drug Targets (2014) 14(4):245-54. doi:10.2174/1871 530314666140922153350

4. Russo MA, Sansone L, Polletta L, Runci A, Rashid MM, De Santis E, et al. Sirtuins and resveratrol-derived compounds: a model for understanding the beneficial effects of the Mediterranean diet. Endocr Metab Immune Disord Drug Targets (2014) 14(4):300-8. doi:10.2174/1871530314666140709093305

5. Bonaccio M, Cerletti C, Iacoviello L, de Gaetano G. Mediterranean diet and low-grade subclinical inflammation: the Moli-sani study. Endocr Metab Immune Disord Drug Targets (2015) 15(1):18-24. doi:10.2174/18715303146 66141020112146

6. Morabito G, Kucan P, Srafini M. Prevention of postprandial metabolic stress in humans: role of fruit-derived products. Endocr Metab Immune Disord Drug Targets (2015) 15(1):46-53. doi:10.2174/1871530314666141021114325

7. Watson RR, Preedy V, Zibaldi S. Polyphenols in Human Health and Disease. (Vol. 1-2). New York, NY: Elsevier (2014).

8. Magrone T, Kumazawa Y, Jirillo E. Polyphenol-mediated beneficial effects in healthy status and disease with special references to immune-based mechanisms. In: Watson RR, Preedy V, Zibaldi S, editors. Polyphenols in Human Health and Disease. (Vol. 1), Oxford, UK: Elsevier (2014). p. 467-79.

9. McShea A, Leissle K, Smith MA. The essence of chocolate: a rich, dark, and well-kept secret. Nutrition (2009) 25(11-12):1104-5. doi:10.1016/j.nut.2009. 05.012
Conclusively, in the light of the above considerations, cocoa and dark chocolate-based diet may be beneficial in aged people for improvement of the neuro-cardiovascular connectivity.

\section{AUTHOR CONTRIBUTIONS}

All authors equally contributed to the compilation of the present review.

\section{ACKNOWLEDGMENTS}

This is a short text to acknowledge the contributions of specific colleagues, institutions, or agencies that aided the efforts of the authors.

\section{FUNDING}

This paper was supported by "Intervento cofinanziato dal Fondo di Sviluppo e Coesione 2007-2013-APQ Ricerca Regione Puglia Programma regionale a sostegno della specializzazione intelligente e della sostenibilità sociale ed ambientaleFutureInResearch."

UNIONE EUROPEA

10. Bracco U. Effect of triglyceride structure on fat absorption. Am J Clin Nutr (1994) 60(6 Suppl):1002S-9S.

11. Hunter JE, Zhang J, Kris-Etherton PM. Cardiovascular disease risk of dietary stearic acid compared with trans, other saturated, and unsaturated fatty acids: a systematic review. Am J Clin Nutr (2010) 91(1):46-63. doi:10.3945/ ajcn.2009.27661

12. Jenkins DJ, Kendall CW, Vuksan V, Vidgen E, Wong E, Augustin LS, et al. Effect of cocoa bran on low-density lipoprotein oxidation and fecal bulking. Arch Intern Med (2000) 160(15):2374-9. doi:10.1001/ archinte.160.15.2374

13. Weickert MO, Pfeiffer AF. Metabolic effects of dietary fiber consumption and prevention of diabetes. J Nutr (2008) 138(3):439-42.

14. Steinberg FM, Bearden MM, Keen CL. Cocoa and chocolate flavonoids: implications for cardiovascular health. J Am Diet Assoc (2003) 103(2):215-23. doi:10.1053/jada.2003.50028

15. Ueshima K. Magnesium and ischemic heart disease: a review of epidemiological, experimental, and clinical evidences. Magnes Res (2005) 18(4):275-84.

16. Saari JT. Copper deficiency and cardiovascular disease: role of peroxidation, glycation, and nitration. Can J Physiol Pharmacol (2000) 78(10):848-55. doi:10.1139/y00-054

17. Ando K, Matsui H, Fujita M, Fujita T. Protective effect of dietary potassium against cardiovascular damage in salt-sensitive hypertension: possible role of its antioxidant action. Curr Vasc Pharmacol (2010) 8(1):59-63. doi:10.2174/157016110790226561

18. World Health Organization. In: De Benoist B, editor. Worldwide Prevalence of Anaemia 1993-2005. WHO Global Database of Anaemia. Geneva: World Health Organization (2008). p. 1-40.

19. Wollgast J, Anklam E. Review on polyphenols in Theobroma cacao: changes in composition during the manufacture of chocolate and methodology for identification and quantification. Food Res Intern (2000) 33(6):423-47. doi:10.1016/S0963-9969(00)00068-5 
20. Porter LJ, Ma Z, Chan BG. Cacao proacyanidins: major flavonoids and identification of some minor metabolites. Phytochemistry (1991) 30:1657-63. doi:10.1016/0031-9422(91)84228-K

21. Schroeter H, Heiss C, Balzer J, Kleinbongard P, Keen CL, Hollenberg NK, et al. (-)-Epicatechin mediates beneficial effects of flavanol-rich cocoa on vascular function in humans. Proc Natl Acad Sci U S A (2006) 103(4):1024-9. doi:10.1073/pnas.0510168103

22. Hurst WJ, Glinski JA, Miller KB, Apgar J, Davey MH, Stuart DA. Survey of the trans-resveratrol and trans-piceid content of cocoa-containing and chocolate products. J Agric Food Chem (2008) 56(18):8374-8. doi:10.1021/jf801297w

23. Lamuela-Raventós RM, Andrés-Lacueva C, Permanyer J, IzquierdoPulido M. More antioxidants in cocoa. J Nutr (2001) 131(3):834-5.

24. Sánchez-Rabaneda F, Jáuregui O, Casals I, Andrés-Lacueva C, IzquierdoPulido M, Lamuela-Raventós RM. Liquid chromatographic/electrospray ionization tandem mass spectrometric study of the phenolic composition of cocoa (Theobroma cacao). J Mass Spectrom (2003) 38(1):35-42. doi:10.1002/ jms.395

25. Zhu QY, Holt RR, Lazarus SA, Ensunsa JL, Hammerstone JF, Schmitz HH, et al. Stability of the flavan-3-ols epicatechin and catechin and related dimeric procyanidins derived from cocoa. J Agric Food Chem (2002) 50(6):1700-5. doi:10.1021/jf011228o

26. Santos-Buelga C, Scalbert A. Proanthocyanidins and tannin-like compoundsnature, occurrence, dietary intake and effects on nutrition and health. J Sci Food Agric (2000) 80(7):1094-117. doi:10.1002/(SICI)1097-0010 (20000515)80:7<1094:AID-JSFA569>3.0.CO;2-1

27. Actis-Goretta L, Lévèques A, Rein $M$, Teml A, Schäfer C, Hofmann U, et al. Intestinal absorption, metabolism, and excretion of (-)-epicatechin in healthy humans assessed by using an intestinal perfusion technique. Am J Clin Nutr (2013) 98(4):924-33. doi:10.3945/ajcn.113.065789

28. Holt RR, Lazarus SA, Sullards MC, Zhu QY, Schramm DD, Hammerstone JF, et al. Procyanidin dimer B2 [epicatechin-(4beta-8)-epicatechin] in human plasma after the consumption of a flavanol-rich cocoa. Am J Clin Nutr (2002) 76(4):798-804.

29. Ottaviani JI, Momma TY, Heiss C, Kwik-Uribe C, Schroeter H, Keen CL. The stereochemical configuration of flavanols influences the level and metabolism of flavanols in humans and their biological activity in vivo. Free Radic Biol Med (2011) 50(2):237-44. doi:10.1016/j.freeradbiomed.2010.11.005

30. Bravo L. Polyphenols: chemistry, dietary sources, metabolism, and nutritional significance. Nutr Rev (1998) 56(11):317-33. doi:10.1111/j.1753-4887.1998. tb01670.x

31. Actis-Goretta L, Lévèques A, Giuffrida F, Romanov-Michailidis F, Viton F, Barron D, et al. Elucidation of (-)-epicatechin metabolites after ingestion of chocolate by healthy humans. Free Radic Biol Med (2012) 53(4):787-95. doi:10.1016/j.freeradbiomed.2012.05.023

32. Ottaviani JI, Momma TY, Kuhnle GK, Keen CL, Schroeter H. Structurally related (-)-epicatechin metabolites in humans: assessment using de novo chemically synthesized authentic standards. Free Radic Biol Med (2012) 52(8):1403-12. doi:10.1016/j.freeradbiomed.2011.12.010

33. Monagas M, Urpi-Sarda M, Sánchez-Patán F, Llorach R, Garrido I, GómezCordovés $\mathrm{C}$, et al. Insights into the metabolism and microbial biotransformation of dietary flavan-3-ols and the bioactivity of their metabolites. Food Funct (2010) 1(3):233-53. doi:10.1039/c0fo00132e

34. Meng X, Sang S, Zhu N, Lu H, Sheng S, Lee MJ, et al. Identification and characterization of methylated and ring-fission metabolites of tea catechins formed in humans, mice, and rats. Chem Res Toxicol (2002) 15(8):1042-50. doi:10.1021/tx010184a

35. Rios LY, Gonthier MP, Rémésy C, Mila I, Lapierre C, Lazarus SA, et al. Chocolate intake increases urinary excretion of polyphenol-derived phenolic acids in healthy human subjects. Am J Clin Nutr (2003) 77(4):912-8.

36. Urpi-Sarda M, Llorach R, Khan N, Monagas M, Rotches-Ribalta M, LamuelaRaventos R, et al. Effect of milk on the urinary excretion of microbial phenolic acids after cocoa powder consumption in humans. J Agric Food Chem (2010) 58(8):4706-11. doi:10.1021/jf904440h

37. Urpi-Sarda M, Monagas M, Khan N, Lamuela-Raventos RM, SantosBuelga C, Sacanella E, et al. Epicatechin, procyanidins, and phenolic microbial metabolites after cocoa intake in humans and rats. Anal Bioanal Chem (2009) 394(6):1545-56. doi:10.1007/s00216-009-2676-1
38. Depeint F, Gee JM, Williamson G, Johnson IT. Evidence for consistent patterns between flavonoid structures and cellular activities. Proc Nutr Soc (2002) 61(1):97-103. doi:10.1079/PNS2001133

39. Scalbert A, Williamson G. Dietary intake and bioavailability of polyphenols. J Nutr (2000) 130(8S Suppl):2073S-85S.

40. Lozupone CA, Stombaugh JI, Gordon JI, Jansson JK, Knight R. Diversity, stability and resilience of the human gut microbiota. Nature (2012) 489(7415):220-30. doi:10.1038/nature11550

41. Blacher E, Levy M, Tatirovsky E, Elinav E. Microbiome-modulated metabolites at the interface of host immunity. J Immunol (2017) 198(2):572-80. doi:10.4049/jimmunol.1601247

42. Martin FP, Montoliu I, Nagy K, Moco S, Collino S, Guy P, et al. Specific dietary preferences are linked to differing gut microbial metabolic activity in response to dark chocolate intake. J Proteome Res (2012) 11(12):6252-63. doi:10.1021/pr300915z

43. Criqui MH, Ringel BL. Does diet or alcohol explain the French paradox? Lancet (1994) 344(8939-8940):1719-23. doi:10.1016/S0140-6736 (94)92883-5

44. Renaud S, de Lorgeril M. Wine, alcohol, platelets, and the French paradox for coronary heart disease. Lancet (1992) 339(8808):1523-6. doi:10.1016/ 0140-6736(92)91277-F

45. Fisher ND, Hughes M, Gerhard-Herman M, Hollenbergh NK. Flavanol-rich cocoa induces nitric-oxide-dependent vasodilation in healthy humans. J Hypertens (2003) 21(12):2281-6. doi:10.1097/01.hjh.0000084783.15238.eb

46. Fisher ND, Hollenberg NK. Aging and vascular responses to flavanol-rich cocoa. J Hypertens (2006) 24(8):1575-80. doi:10.1097/01.hjh.0000239293. 40507.2a

47. Faridi Z, Njike VY, Dutta S, Ali A, Katz DL. Acute dark chocolate and cocoa ingestion and endothelial function: a randomized controlled crossover trial. Am J Clin Nutr (2008) 88(1):58-63.

48. Njike VY, Faridi Z, Shuval K, Dutta S, Kay CD, West SG, et al. Effects of sugar-sweetened and sugar-free cocoa on endothelial function in overweight adults. Int J Cardiol (2011) 149(1):83-8. doi:10.1016/j.ijcard.2009.12.010

49. Engler MB, Engler MM, Chen CY, Malloy MJ, Browne A, Chiu EY, et al. Flavonoid-rich dark chocolate improves endothelial function and increases plasma epicatechin concentrations in healthy adults. J Am Coll Nutr (2004) 23(3):197-204. doi:10.1016/j.ijcard.2009.12.010

50. Shiina Y, Funabashi N, Lee K, Murayama T, Nakamura K, Wakatsuki Y, et al. Acute effect of oral flavonoid-rich dark chocolate intake on coronary circulation, as compared with non-flavonoid white chocolate, by transthoracic Doppler echocardiography in healthy adults. Int J Cardiol (2009) 131(3):424-9. doi:10.1016/j.ijcard.2007.07.131

51. Hollenberg NK, Fisher ND, McCullough ML. Flavanols, the Kuna, cocoa consumption, and nitric oxide. J Am Soc Hypertens (2009) 3(2):105-12. doi:10.1016/j.jash.2008.11.001

52. Hollenberg NK, Martinez G, McCullough M, Meinking T, Passan D, Preston M, et al. Aging, acculturation, salt intake, and hypertension in the Kuna of Panama. Hypertension (1997) 29(1 Pt 2):171-6. doi:10.1161/01. HYP.29.1.171

53. Heiss C, Dejam A, Kleinbongard P, Schewe T, Sies H, Kelm M. Vascular effects of cocoa rich in flavan-3-ols. JAMA (2003) 290(8):1030-1. doi:10.1001/ jama.290.8.1030

54. Heiss C, Finis D, Kleinbongard P, Hoffmann A, Rassaf T, Kelm M, et al. Sustained increase in flow-mediated dilation after daily intake of highflavanol cocoa drink over 1 week. J Cardiovasc Pharmacol (2007) 49(2):74-80. doi:10.1097/FJC.0b013e31802d0001

55. Balzer J, Rassaf T, Heiss C, Kleinbongard P, Lauer T, Merx M, et al. Sustained benefits in vascular function through flavanol-containing cocoa in medicated diabetic patients a double-masked, randomized, controlled trial. J Am Coll Cardiol (2008) 51(22):2141-9. doi:10.1016/j.jacc.2008.01.059

56. Farouque HM, Leung M, Hope SA, Baldi M, Schechter C, Cameron JD, et al. Acute and chronic effects of flavanol-rich cocoa on vascular function in subjects with coronary artery disease: a randomized double-blind placebo-controlled study. Clin Sci (Lond) (2006) 111(1):71-80. doi:10.1042/CS20060048

57. Heiss C, Jahn S, Taylor M, Real WM, Angeli FS, Wong ML, et al. Improvement of endothelial function with dietary flavanols is associated with mobilization of circulating angiogenic cells in patients with coronary artery disease. J Am Coll Cardiol (2010) 56(3):218-24. doi:10.1016/j.jacc.2010.03.039 
58. Flammer AJ, Hermann F, Sudano I, Spieker L, Hermann M, Cooper KA, et al. Dark chocolate improves coronary vasomotion and reduces platelet reactivity. Circulation (2007) 116(21):2376-82. doi:10.1161/ CIRCULATIONAHA.107.713867

59. Vogel RA. Measurement of endothelial function by brachial artery flowmediated vasodilation. Am J Cardiol (2001) 88(2A):31E-4E. doi:10.1016/ S0002-9149(01)01764-7

60. Yeboah J, Crouse JR, Hsu FC, Burke GL, Herrington DM. Brachial flow-mediated dilation predicts incident cardiovascular events in older adults: the Cardiovascular Health Study. Circulation (2007) 115(18):2390-7. doi:10.1161/CIRCULATIONAHA.106.678276

61. Yeboah J, Folsom AR, Burke GL, Johnson C, Polak JF, Post W, et al. Predictive value of brachial flow-mediated dilation for incident cardiovascular events in a population-based study: the multi-ethnic study of atherosclerosis. Circulation (2009) 120(6):502-9. doi:10.1161/CIRCULATIONAHA.109.864801

62. Selmi C, Cocchi CA, Lanfredini M, Keen CL, Gershwin ME. Chocolate at heart: the anti-inflammatory impact of cocoa flavanols. Mol Nutr Food Res (2008) 52(11):1340-8. doi:10.1002/mnfr.200700435

63. Magrone T, Candore G, Caruso C, Jirillo E, Covelli V. Polyphenols from red wine modulate immune responsiveness: biological and clinical significance. Curr Pharm Des (2008) 14(26):2733-48. doi:10.2174/138161208786264098

64. Moreno-Ulloa A, Romero-Perez D, Villarreal F, Ceballos G, Ramirez-Sanchez I. Cell membrane mediated (-)-epicatechin effects on upstream endothelial cell signaling: evidence for a surface receptor. Bioorg Med Chem Lett (2014) 24(12):2749-52. doi:10.1016/j.bmcl.2014.04.038

65. Moncada S, Higgs A. The L-arginine-nitric oxide pathway. N Engl J Med (1993) 329(27):2002-12. doi:10.1056/NEJM199312303292706

66. Moncada S, Palmer RM, Higgs EA. Nitric oxide: physiology, pathophysiology, and pharmacology. Pharmacol Rev (1991) 43(2):109-42.

67. Mitchell JA, Ali F, Bailey L, Moreno L, Harrington LS. Role of nitric oxide and prostacyclin as vasoactive hormones released by the endothelium. Exp Physiol (2008) 93(1):141-7. doi:10.1113/expphysiol.2007.038588

68. Schramm DD, Karim M, Schrader HR, Holt RR, Kirkpatrick NJ, Polagruto JA, et al. Food effects on the absorption and pharmacokinetics of cocoa flavanols. Life Sci (2003) 73(7):857-69. doi:10.1016/S0024-3205(03)00373-4

69. Schwab US, Maliranta HM, Sarkkinen ES, Savolainen MJ, Kesäniemi YA, Uusitupa MI. Different effects of palmitic and stearic acid-enriched diets on serum lipids and lipoproteins and plasma cholesteryl ester transfer protein activity in healthy young women. Metabolism (1996) 45(2):143-9. doi:10.1016/S0026-0495(96)90044-X

70. Steffen Y, Schewe T, Sies H. (-)-Epicatechin elevates nitric oxide in endothelial cells via inhibition of NADPH oxidase. Biochem Biophys Res Commun (2007) 359(3):828-33. doi:10.1016/j.bbrc.2007.05.200

71. Schewe T, Steffen Y, Sies H. How do dietary flavanols improve vascular function? A position paper. Arch Biochem Biophys (2008) 476(2):102-6. doi:10.1016/j.abb.2008.03.004

72. Rein D, Paglieroni TG, Pearson DA, Wun T, Schmitz HH, Gosselin R, et al. Cocoa and wine polyphenols modulate platelet activation and function. J Nutr (2000) 130(8S Suppl):2120S-6S.

73. Bucki R, Pastore JJ, Giraud F, Sulpice JC, Janmey PA. Flavonoid inhibition of platelet procoagulant activity and phosphoinositide synthesis. J Thromb Haemost (2003) 1(8):1820-8. doi:10.1046/j.1538-7836.2003.00294.x

74. Pignatelli P, Pulcinelli FM, Celestini A, Lenti L, Ghiselli A, Gazzaniga PP, et al. The flavonoids quercetin and catechin synergistically inhibit platelet function by antagonizing the intracellular production of hydrogen peroxide. Am J Clin Nutr (2000) 72(5):1150-5.

75. Guerrero JA, Lozano ML, Castillo J, Benavente-García O, Vicente V, Rivera J. Flavonoids inhibit platelet function through binding to the thromboxane A2 receptor. J Thromb Haemost (2005) 3(2):369-76. doi:10.1111/j.1538-7836.2004.01099.x

76. Rein D, Paglieroni TG, Wun T, Pearson DA, Schmitz HH, Gosselin R, et al. Cocoa inhibits platelet activation and function. Am JClin Nutr (2000) 72(1):30-5.

77. Holt RR, Schramm DD, Keen CL, Lazarus SA, Schmitz HH. Chocolate consumption and platelet function. JAMA (2002) 287(17):2212-3. doi:10.1001/ jama.287.17.2209

78. Murphy KJ, Chronopoulos AK, Singh I, Francis MA, Moriarty H, Pike MJ, et al. Dietary flavanols and procyanidin oligomers from cocoa (Theobroma cacao) inhibit platelet function. Am J Clin Nutr (2003) 77(6):1466-73.
79. Hamed MS, Gambert S, Bliden KP, Bailon O, Singla A, Antonino MJ, et al. Dark chocolate effect on platelet activity, C-reactive protein and lipid profile: a pilot study. South Med J (2008) 101(12):1203-8. doi:10.1097/ SMJ.0b013e31818859eb

80. Ostertag LM, O’Kennedy N, Kroon PA, Duthie GG, de Roos B. Impact of dietary polyphenols on human platelet function - a critical review of controlled dietary intervention studies. Mol Nutr Food Res (2010) 54(1):60-81. doi:10.1002/mnfr.200900172

81. Flammer AJ, Sudano I, Wolfrum M, Thomas R, Enseleit F, Périat D, et al. Cardiovascular effects of flavanol-rich chocolate in patients with heart failure. Eur Heart J (2012) 33(17):2172-80. doi:10.1093/eurheartj/ ehr448

82. Napoli C, Ignarro LJ. Nitric oxide and pathogenic mechanisms involved in the development of vascular diseases. Arch Pharm Res (2009) 32(8):1103-8. doi:10.1007/s12272-009-1801-1

83. Actis-Goretta L, Ottaviani JI, Fraga CG. Inhibition of angiotensin converting enzyme activity by flavanol-rich foods. J Agric Food Chem (2006) 54(1):229-34. doi:10.1021/jf052263o

84. Actis-Goretta L, Ottaviani JI, Keen CL, Fraga CG. Inhibition of angiotensin converting enzyme (ACE) activity by flavan-3-ols and procyanidins. FEBS Lett (2003) 555(3):597-600. doi:10.1016/S0014-5793(03)01355-3

85. Lavoie JL, Sigmund CD. Minireview: overview of the renin-angiotensin system - an endocrine and paracrine system. Endocrinology (2003) 144(6):2179-83. doi:10.1210/en.2003-0150

86. Shrime MG, Bauer SR, McDonald AC, Chowdhury NH, Coltart CE, Ding EL. Flavonoid-rich cocoa consumption affects multiple cardiovascular risk factors in a meta-analysis of short-term studies. J Nutr (2011) 141(11):1982-8. doi:10.3945/jn.111.145482

87. Grassi D, Necozione S, Lippi C, Croce G, Valeri L, Pasqualetti P, et al. Cocoa reduces blood pressure and insulin resistance and improves endotheliumdependent vasodilation in hypertensives. Hypertension (2005) 46(2):398-405. doi:10.1161/01.HYP.0000174990.46027.70

88. Mellor DD, Sathyapalan T, Kilpatrick ES, Beckett S, Atkin SL. High-cocoa polyphenol-rich chocolate improves HDL cholesterol in type 2 diabetes patients. Diabet Med (2010) 27(11):1318-21. doi:10.1111/ j.1464-5491.2010.03108.x

89. Baba S, Natsume M, Yasuda A, Nakamura Y, Tamura T, Osakabe N, et al. Plasma LDL and HDL cholesterol and oxidized LDL concentrations are altered in normo- and hypercholesterolemic humans after intake of different levels of cocoa powder. J Nutr (2007) 137(6):1436-41.

90. Baba S, Osakabe N, Kato Y, Natsume M, Yasuda A, Kido T, et al. Continuous intake of polyphenolic compounds containing cocoa powder reduces LDL oxidative susceptibility and has beneficial effects on plasma HDL-cholesterol concentrations in humans. Am J Clin Nutr (2007) 85(3):709-17.

91. Kris-Etherton PM, Derr JA, Mustad VA, Seligson FH, Pearson TA. Effects of a milk chocolate bar per day substituted for a high-carbohydrate snack in young men on an NCEP/AHA step 1 diet. Am J Clin Nutr (1994) 60(6 Suppl):1037S-42S.

92. Mursu J, Voutilainen S, Nurmi T, Rissanen TH, Virtanen JK, Kaikkonen J, et al. Dark chocolate consumption increases HDL cholesterol concentration and chocolate fatty acids may inhibit lipid peroxidation in healthy humans. Free Radic Biol Med (2004) 37(9):1351-9. doi:10.1016/j. freeradbiomed.2004.06.002

93. Almoosawi S, Fyfe L, Ho C, Al-Dujaili E. The effect of polyphenol-rich dark chocolate on fasting capillary whole blood glucose, total cholesterol, blood pressure and glucocorticoids in healthy overweight and obese subjects. Br J Nutr (2010) 103(6):842-50. doi:10.1017/S0007114509992431

94. Crews WD Jr, Harrison DW, Wright JW. A double-blind, placebo-controlled, randomized trial of the effects of dark chocolate and cocoa on variables associated with neuropsychological functioning and cardiovascular health: clinical findings from a sample of healthy, cognitively intact older adults. Am J Clin Nutr (2008) 87(4):872-80.

95. Muniyappa R, Hall G, Kolodziej TL, Karne RJ, Crandon SK, Quon MJ. Cocoa consumption for $2 \mathrm{wk}$ enhances insulin-mediated vasodilatation without improving blood pressure or insulin resistance in essential hypertension. Am J Clin Nutr (2008) 88(6):1685-96. doi:10.3945/ajcn.2008.26457

96. Ramiro-Puig E, Casadesús G, Lee HG, Zhu X, McShea A, Perry G, et al. Neuroprotective effect of cocoa flavonoids on in vitro oxidative stress. Eur J Nutr (2009) 48(1):54-61. doi:10.1007/s00394-008-0761-4 
97. Macready AL, Kennedy OB, Ellis JA, Williams CM, Spencer JP, Butler LT. Flavonoids and cognitive function: a review of human randomized controlled trial studies and recommendations for future studies. Genes Nutr (2009) 4(4):227-42. doi:10.1007/s12263-009-0135-4

98. Weinmann S, Roll S, Schwarzbach C, Vauth C, Willich SN. Effects of Ginkgo biloba in dementia: systematic review and meta-analysis. BMC Geriatr (2010) 10:14. doi:10.1186/1471-2318-10-14

99. Yu S, Wang X, He X, Wang Y, Gao S, Ren L, et al. Curcumin exerts antiinflammatory and antioxidative properties in 1-methyl-4-phenylpyridinium ion $(\mathrm{MPP}(+))$-stimulated mesencephalic astrocytes by interference with TLR4 and downstream signaling pathway. Cell Stress Chaperones (2016) 21(4):697-705. doi:10.1007/s12192-016-0695-3

100. Rahimifard M, Maqbool F, Moeini-Nodeh S, Niaz K, Abdollahi M, Braidy N, et al. Targeting the TLR4 signaling pathway by polyphenols: a novel therapeutic strategy for neuroinflammation. Ageing Res Rev (2017) 36:11-9. doi:10.1016/j.arr.2017.02.004

101. Kelleher RJ III, Govindarajan A, Jung HY, Kang H, Tonegawa S. Translational control by MAPK signaling in long-term synaptic plasticity and memory. Cell (2004) 116(3):467-79. doi:10.1016/S0092-8674(04)00115-1

102. Goyarzu P, Malin DH, Lau FC, Taglialatela G, Moon WD, Jennings R, et al. Blueberry supplemented diet: effects on object recognition memory and nuclear factor-kappa B levels in aged rats. Nutr Neurosci (2004) 7(2):75-83. d oi:10.1080/10284150410001710410

103. Kim DH, Jeon SJ, Son KH, Jung JW, Lee S, Yoon BH, et al. Effect of the flavonoid, oroxylin A, on transient cerebral hypoperfusion-induced memory impairment in mice. Pharmacol Biochem Behav (2006) 85(3):658-68. doi:10.1016/j.pbb.2006.10.025

104. Valente T, Hidalgo J, Bolea I, Ramirez B, Anglés N, Reguant J, et al. A diet enriched in polyphenols and polyunsaturated fatty acids, LMN diet, induces neurogenesis in the subventricular zone and hippocampus of adult mouse brain. J Alzheimers Dis (2009) 18(4):849-65. doi:10.3233/JAD-20091188

105. Nehlig A. The neuroprotective effects of cocoa flavanol and its influence on cognitive performance. Br J Pharmacol (2013) 75(3):716-27. doi:10.1111/j.1365-2125.2012.04378.x

106. Fisher ND, Sorond FA, Hollenberg NK. Cocoa flavanols and brain perfusion. J Cardiovasc Pharmacol (2006) 47(Suppl 2):S210-4. doi:10.1097/ 00005344-200606001-00017

107. Huber KK, Adams H, Remky A, Arend KO. Retrobulbar haemodynamics and contrast sensitivity improvements after $\mathrm{CO}_{2}$ breathing. Acta Ophthalmol Scand (2006) 84(4):481-7. doi:10.1111/j.1600-0420.2006.00687.x

108. Kalt W, Hanneken A, Milbury P, Tremblay F. Recent research on polyphenolics in vision and eye health. J Agric Food Chem (2010) 58(7):4001-7. doi:10.1021/jf903038r

109. van Praag H, Lucero MJ, Yeo GW, Stecker K, Heivand N, Zhao C, et al. Plant-derived flavanol (-)epicatechin enhances angiogenesis and retention of spatial memory in mice. J Neurosci (2007) 27(22):5869-78. doi:10.1523/ JNEUROSCI.0914-07.2007

110. Spencer JP. Flavonoids and brain health: multiple effects underpinned by common mechanisms. Genes Nutr (2009) 4(4):243-50. doi:10.1007/ s12263-009-0136-3

111. Hunot S, Hirsch EC. Neuroinflammatory processes in Parkinson's disease. Ann Neurol (2003) 53(Suppl 3):S49-58; discussion S58-60. doi:10.1002/ ana.10481

112. Spencer JP. The interactions of flavonoids within neuronal signalling pathways. Genes Nutr (2007) 2(3):257-73. doi:10.1007/s12263-0070056-z

113. Joseph JA, Shukitt-Hale B, Denisova NA, Bielinski D, Martin A, McEwen JJ, et al. Reversals of age-related declines in neuronal signal transduction, cognitive, and motor behavioral deficits with blueberry, spinach, or strawberry dietary supplementation. J Neurosci (1999) 19(18):8114-21.

114. Marzulli G, Magrone T, Vonghia L, Kaneko M, Takimoto H, Kumazawa Y, et al. Immunomodulating and anti-allergic effects of Negroamaro and Koshu Vitis vinifera fermented grape marc (FGM). Curr Pharm Des (2014) 20(6):864-8. doi:10.2174/138161282006140220120640

115. Walsh DM, Selkoe DJ. A critical appraisal of the pathogenic protein spread hypothesis of neurodegeneration. Nat Rev Neurosci (2016) 17(4):251-60. doi:10.1038/nrn.2016.13
116. Cimini A, Gentile R, D’Angelo B, Benedetti E, Cristiano L, Avantaggiati ML, et al. Cocoa powder triggers neuroprotective and preventive effects in a human Alzheimer's disease model by modulating BDNF signaling pathway. J Cell Biochem (2013) 114(10):2209-20. doi:10.1002/jcb.24548

117. Deng H, Mi MT. Resveratrol attenuates A $\beta 25-35$ caused neurotoxicity by inducing autophagy through the TyrRS-PARP1-SIRT1 signaling pathway. Neurochem Res (2016) 41(9):2367-79. doi:10.1007/s11064-016-1950-9

118. Ajami M, Pazoki-Toroudi H, Amani H, Nabavi SF, Braidy N, Vacca RA, et al. Therapeutic role of sirtuins in neurodegenerative disease and their modulation by polyphenols. Neurosci Biobehav Rev (2017) 73:39-47. doi:10.1016/j. neubiorev.2016.11.022

119. Almeida S, Alves MG, Sousa M, Oliveira PF, Silva BM. Are polyphenols strong dietary agents against neurotoxicity and neurodegeneration? Neurotox Res (2016) 30(3):345-66. doi:10.1007/s12640-015-9590-4

120. Gao J, Zhou R, You X, Luo F, He H, Chang X, et al. Salidroside suppresses inflammation in a D-galactose-induced rat model of Alzheimer's disease via SIRT1/NF-кB pathway. Metab Brain Dis (2016) 31(4):771-8. doi:10.1007/ s11011-016-9813-2

121. Madhavadas S, Kapgal VK, Kutty BM, Subramanian S. The neuroprotective effect of dark chocolate in monosodium glutamate-induced nontransgenic Alzheimer disease model rats: biochemical, behavioral, and histological studies. J Diet Suppl (2016) 13(4):449-60. doi:10.3109/19390211.2015.1108946

122. Francis ST, Head K, Morris PG, Macdonald IA. The effect of flavanol-rich cocoa on the fMRI response to a cognitive task in healthy young people. J Cardiovasc Pharmacol (2006) 47(Suppl 2):S215-20. doi:10.1097/00005344200606001-00018

123. Sorond FA, Lipsitz LA, Hollenberg NK, Fisher ND. Cerebral blood flow response to flavanol-rich cocoa in healthy elderly humans. Neuropsychiatr Dis Treat (2008) 4(2):433-40. doi:10.2147/NDT.S2310

124. Macht M, Dettmer D. Everyday mood and emotions after eating a chocolate bar or an apple. Appetite (2006) 46(3):332-6. doi:10.1016/j.appet.2006.01.014

125. Macht M, Mueller J. Immediate effects of chocolate on experimentally induced mood states. Appetite (2007) 49(3):667-74. doi:10.1016/j.appet.2007.05.004

126. Ottley C. Food and mood. Nurs Stand (2000) 15(2):46-52; quiz 54-5.

127. Parker G, Parker I, Brotchie H. Mood state effects of chocolate. J Affect Disord (2006) 92(2-3):149-59. doi:10.1016/j.jad.2006.02.007

128. Scholey AB, French SJ, Morris PJ, Kennedy DO, Milne AL, Haskell CF. Consumption of cocoa flavanols results in acute improvements in mood and cognitive performance during sustained mental effort. J Psychopharmacol (2010) 24(10):1505-14. doi:10.1177/0269881109106923

129. Jagla F, Pechanova O. Age-related cognitive impairment as a sign of geriatric neurocardiovascular interactions: may polyphenols play a protective role? Oxid Med Cell Longev (2015) 2015:721514. doi:10.1155/2015/721514

130. Small DM, Zatorre RJ, Dagher A, Evans AC, Jones-Gotman M. Changes in brain activity related to eating chocolate: from pleasure to aversion. Brain (2001) 124(Pt 9):1720-33. doi:10.1093/brain/124.9.1720

131. Smits M, Peeters RR, van Hecke P, Sunaert S. A 3 T event-related functional magnetic resonance imaging (fMRI) study of primary and secondary gustatory cortex localization using natural tastants. Neuroradiology (2007) 49(1):61-71. doi:10.1007/s00234-006-0160-6

132. Martin GN. Human electroencephalographic (EEG) response to olfactory stimulation: two experiments using the aroma of food. Int J Psychophysiol (1998) 30(3):287-302. doi:10.1016/S0167-8760(98)00025-7

133. Rolls ET, McCabe C. Enhanced affective brain representations of chocolate in cravers vs. non-cravers. Eur J Neurosci (2007) 26(4):1067-76. doi:10.1111/j.1460-9568.2007.05724.x

134. Romier B, Schneider YJ, Larondelle Y, During A. Dietary polyphenols can modulate the intestinal inflammatory response. Nutr Rev (2009) 67(7):36378. doi:10.1111/j.1753-4887.2009.00210.x

135. Magrone T, Jirillo E. Polyphenols from red wine are potent modulators of innate and adaptive immune responsiveness. Proc Nutr Soc (2010) 69(3):279-85. doi:10.1017/S0029665110000121

136. Kumazawa Y, Kawaguchi K, Takimoto H. Immunomodulating effects of flavonoids on acute and chronic inflammatory responses caused by tumor necrosis factor alpha. Curr Pharm Des (2006) 12(32):4271-9. doi:10.2174/138161206778743565

137. Pérez-Berezo T, Ramírez-Santana C, Franch A, Ramos-Romero S, Castellote C, Pérez-Cano FJ, et al. Effects of a cocoa diet on an intestinal inflammation 
model in rats. Exp Biol Med (Maywood) (2012) 237(10):1181-8. doi:10.1258/ ebm.2012.012083

138. Andújar I, Recio MC, Giner RM, Cienfuegos-Jovellanos E, Laghi S, Muguerza B, et al. Inhibition of ulcerative colitis in mice after oral administration of a polyphenol-enriched cocoa extract is mediated by the inhibition of STAT1 and STAT3 phosphorylation in colon cells. J Agric Food Chem (2011) 59(12):6474-83. doi:10.1021/jf2008925

139. Vázquez-Agell $M$, Urpi-Sarda $M$, Sacanella $E$, Camino-López $S$, Chiva-Blanch G,Llorente-Cortés V, et al. Cocoa consumption reduces NF- $\mathrm{kB}$ activation in peripheral blood mononuclear cells in humans. Nutr Metab Cardiovasc Dis (2013) 23(3):257-63. doi:10.1016/j.numecd.2011.03.015

140. Shapiro H, Singer P, Halpern Z, Bruck R. Polyphenols in the treatment of inflammatory bowel disease and acute pancreatitis. Gut (2007) 56(3):426-35. doi:10.1136/gut.2006.094599

141. Matsui N, Ito R, Nishimura E, Yoshikawa M, Kato M, Kamei M, et al. Ingested cocoa can prevent high-fat diet-induced obesity by regulating the expression of genes for fatty acid metabolism. Nutrition (2005) 21(5):594-601. doi:10.1016/j.nut.2004.10.008

142. Massolt ET, van Haard PM, Rehfeld JF, Posthuma EF, van der Veer E, Schweitzer DH. Appetite suppression through smelling of dark chocolate correlates with changes in ghrelin in young women. Regul Pept (2010) 161(1-3):81-6. doi:10.1016/j.regpep.2010.01.005

143. Tschöp M, Smiley DL, Heiman ML. Ghrelin induces adiposity in rodents. Nature (2000) 407(6806):908-13. doi:10.1038/35038090

144. Stienstra R, Duval C, Müller M, Kersten S. PPARs, obesity, and inflammation. PPAR Res (2007) 2007:95974. doi:10.1155/2007/95974

145. Staels B, Auwerx J. Regulation of apo A-I gene expression by fibrates. Atherosclerosis(1998) 137(Suppl):S19-23.doi:10.1016/S0021-9150(97)00313-4

146. Goldwasser J, Cohen PY, Yang E, Balaguer P, Yarmush ML, Nahmias Y. Transcriptional regulation of human and rat hepatic lipid metabolism by the grapefruit flavonoid naringenin: role of PPARalpha, PPARgamma and LXRalpha. PLoS One (2010) 5(8):e12399. doi:10.1371/journal. pone.0012399

147. Ali F, Ismail A, Kersten S. Molecular mechanisms underlying the potential antiobesity-related diseases effect of cocoa polyphenols. Mol Nutr Food Res (2014) 58(1):33-48. doi:10.1002/mnfr.201300277

148. Wiswedel I, Hirsch D, Kropf S, Gruening M, Pfister E, Schewe T, et al. Flavanol-rich cocoa drink lowers plasma $\mathrm{F}(2)$-isoprostane concentrations in humans. Free Radic Biol Med (2004) 37(3):411-21. doi:10.1016/j. freeradbiomed.2004.05.013

149. Da Silva MS, Bilodeau JF, Julien P, Rudkowska I. Dietary fats and F2-isoprostanes: a review of the clinical evidence critical reviews in food science and nutrition. Crit Rev Food Sci Nutr (2016). doi:10.1080/1040839 8.2016.1196646

150. Kurosawa T, Itoh F, Nozaki A, Nakano Y, Katsuda S, Osakabe N, et al. Suppressive effect of cocoa powder on atherosclerosis in Kurosawa and Kusanagi-hypercholesterolemic rabbits. JAtheroscler Thromb (2005) 12(1):20-8. doi:10.5551/jat.12.20

151. Orozco TJ, Wang JF, Keen CL. Chronic consumption of a flavanol- and procyanindin-rich diet is associated with reduced levels of 8-hydroxy-2'deoxyguanosine in rat testes. J Nutr Biochem (2003) 14(2):104-10. doi:10.1016/S0955-2863(02)00273-5

152. Wan Y, Vinson JA, Etherton TD, Proch J, Lazarus SA, Kris-Etherton PM. Effects of cocoa powder and dark chocolate on LDL oxidative susceptibility and prostaglandin concentrations in humans. Am JClin Nutr (2001) 74(5):596-602.

153. Kondo K, Hirano R, Matsumoto A, Igarashi O, Itakura H. Inhibition of LDL oxidation by cocoa. Lancet (1996) 348(9040):1514. doi:10.1016/ S0140-6736(05)65927-2

154. Osakabe N, Baba S, Yasuda A, Iwamoto T, Kamiyama M, Takizawa T, et al. Daily cocoa intake reduces the susceptibility of low-density lipoprotein to oxidation as demonstrated in healthy human volunteers. Free Radic Res (2001) 34(1):93-9. doi:10.1080/10715760100300091

155. Nanetti L, Vignini A, Gregori A, Raffaelli F, Moroni C, Beroli E, et al. Effect of consumption of dark chocolate on lipoproteins and serum lipids. Mediterr J Nutr Metab (2008) 1:25. doi:10.1007/s12349-008-0004-5

156. Wang JF, Schramm DD, Holt RR, Ensunsa JL, Fraga CG, Schmitz HH, et al. A dose-response effect from chocolate consumption on plasma epicatechin and oxidative damage. J Nutr (2000) 130(8S Suppl):2115S-9S.
157. Rimbach G, Melchin M, Moehring J, Wagner AE. Polyphenols from cocoa and vascular health-a critical review. Int J Mol Sci (2009) 10(10):4290-309. doi:10.3390/ijms10104290

158. Taubert D, Berkels R, Roesen R, Klaus W. Chocolate and blood pressure in elderly individuals with isolated systolic hypertension. JAMA (2003) 290(8):1029-30. doi:10.1001/jama.290.8.1029

159. Kawaguchi K, Maruyama H, Hasunuma R, Kumazawa Y. Suppression of inflammatory responses after onset of collagen-induced arthritis in mice by oral administration of the Citrus flavanone naringin. Immunopharmacol Immunotoxicol (2011) 33(4):723-9. doi:10.3109/089 23973.2011.564186

160. Magrone T, Tafaro A, Jirillo F, Amati L, Jirillo E, Covelli V. Elicitation of immune responsiveness against antigenic challenge in age-related diseases: effects of red wine polyphenols. Curr Pharm Des (2008) 14(26):2749-57. doi:10.2174/138161208786264043

161. Marzulli G, Magrone T, Kawaguchi K, Kumazawa Y, Jirillo E. Fermented grape marc (FGM): immunomodulating properties and its potential exploitation in the treatment of neurodegenerative diseases. Curr Pharm Des (2012) 18(1):43-50. doi:10.2174/138161212798919011

162. Magrone T, Jirillo E. Influence of polyphenols on allergic immune reactions: mechanisms of action. Proc Nutr Soc (2012) 71(2):316-21. doi:10.1017/ S0029665112000109

163. Kaneko M, Kanesaka M, Yoneyama M, Tominaga T, Jirillo E, Kumazawa Y. Inhibitory effects of fermented grape marc from Vitis vinifera Negroamaro on antigen-induced degranulation. Immunopharmacol Immunotoxicol (2010) 32(3):454-61. doi:10.3109/08923970903513139

164. Ramiro-Puig E, Urpí-Sardà M, Pérez-Cano FJ, Franch A, Castellote C, Andrés-Lacueva C, et al. Cocoa-enriched diet enhances antioxidant enzyme activity and modulates lymphocyte composition in thymus from young rats. J Agric Food Chem (2007) 55(16):6431-8. doi:10.1021/jf070487w

165. Ramiro-Puig E, Castell M. Cocoa: antioxidant and immunomodulator. $\mathrm{Br}$ J Nutr (2009) 101(7):931-40. doi:10.1017/S0007114508169896

166. Ramiro-Puig E, Pérez-Cano FJ, Ramírez-Santana C, Castellote C, IzquierdoPulido M, Permanyer J, et al. Spleen lymphocyte function modulated by a cocoa-enriched diet. Clin Exp Immunol (2007) 149(3):535-42. doi:10.1111/j. 1365-2249.2007.03430.x

167. Kenny TP, Keen CL, Schmitz HH, Gershwin ME. Immune effects of cocoa procyanidin oligomers on peripheral blood mononuclear cells. Exp Biol Med (Maywood) (2007) 232(2):293-300.

168. Kenny TP, Shu SA, Moritoki Y, Keen CL, Gershwin ME. Cocoa flavanols and procyanidins can modulate the lipopolysaccharide activation of polymorphonuclear cells in vitro. J Med Food (2009) 12(1):1-7. doi:10.1089/ jmf.2007.0263

169. Ramiro E, Franch A, Castellote C, Andrés-Lacueva C, Izquierdo-Pulido M, Castell M. Effect of Theobroma cacao flavonoids on immune activation of a lymphoid cell line. Br JNutr (2005) 93(6):859-66. doi:10.1079/ BJN20051443

170. Ramos-Romero S, Pérez-Cano FJ, Pérez-Berezo T, Castellote C, Franch A, Castell M. Effect of a cocoa flavonoid-enriched diet on experimental autoimmune arthritis. Br J Nutr (2012) 107(4):523-32. doi:10.1017/S000711451100328X

171. Pérez-Berezo T, Ramiro-Puig E, Pérez-Cano FJ, Castellote C, Permanyer J, Franch A, et al. Influence of a cocoa-enriched diet on specific immune response in ovalbumin-sensitized rats. Mol Nutr Food Res (2009) 53(3): 389-97. doi:10.1002/mnfr.200700396

172. Jenny M, Santer E, Klein A, Ledochowski M, Schennach H, Ueberall F, et al. Cacao extracts suppress tryptophan degradation of mitogen-stimulated peripheral blood mononuclear cells. J Ethnopharmacol (2009) 122(2):261-7. doi:10.1016/j.jep.2009.01.011

173. Ramiro-Puig E, Pérez-Cano FJ, Ramos-Romero S, Pérez-Berezo T, Castellote C, Permanyer J, et al. Intestinal immune system of young rats influenced by cocoa-enriched diet. J Nutr Biochem (2008) 19(8):555-65. doi:10.1016/j.jnutbio.2007.07.002

174. Chang YC, Li PC, Chen BC, Chang MS, Wang JL, Chiu WT, et al. Lipoteichoic acid-induced nitric oxide synthase expression in RAW 264.7 macrophages is mediated by cyclooxygenase-2, prostaglandin E2, protein kinase A, p38 MAPK, and nuclear factor-kappaB pathways. Cell Signal (2006) 18(8):1235-43. doi:10.1016/j.cellsig.2005.10.005

175. Sung N-Y, Yang MS, Song DP, Byun E-B, Kim J-K, Park J-H, et al. The procyanidin trimer $\mathrm{C} 1$ induces macrophage activation via $\mathrm{NF}-\mathrm{KB}$ and 
MAPK pathways, leading to Th1 polarization in murine splenocytes. Eur J Pharmacol (2013) 714(1-3):218-28. doi:10.1016/j.ejphar.2013.02.059

176. MacLellan WR, Brand T, Schneider MD. Transforming growth factor-beta in cardiac ontogeny and adaptation. Circ Res (1993) 73(5):783-91. doi:10.1161/01.RES.73.5.783

177. Border WA, Noble NA. Transforming growth factor beta in tissue fibrosis. N Engl J Med (1994) 331(19):1286-92. doi:10.1056/NEJM199411103311907

178. Mao TK, Van De Water J, Keen CL, Schmitz HH, Gershwin ME. Cocoa flavonols and procyanidins promote transforming growth factor-betal homeostasis in peripheral blood mononuclear cells. Exp Biol Med (Maywood) (2003) 228(1):93-9.

179. Lijnen PJ, Petrov VV, Fagard RH. Induction of cardiac fibrosis by transforming growth factor-beta(1). Mol Genet Metab (2000) 71(1-2):418-35. doi:10.1006/mgme.2000.3032

180. Mao TK, Van de Water J, Keen CL, Schmitz HH, Gershwin ME. Effect of cocoa flavanols and their related oligomers on the secretion of interleukin-5 in peripheral blood mononuclear cells. J Med Food (2002) 5(1):17-22. doi:10.1089/109662002753723188

181. Tzounis X, Vulevic J, Kuhnle GG, George T, Leonczak J, Gibson GR, et al. Flavanol monomer-induced changes to the human faecal microflora. $\mathrm{Br}$ J Nutr (2008) 99(4):782-92. doi:10.1017/S0007114507853384

182. Tzounis X, Rodriguez-Mateos A, Vulevic J, Gibson GR, Kwik-Uribe C, Spencer JP. Prebiotic evaluation of cocoa-derived flavanols in healthy humans by using a randomized, controlled, double-blind, crossover intervention study. Am JClin Nutr (2011) 93(1):62-72. doi:10.3945/ ajcn. 110.000075

183. Wiese S, Esatbeyoglu T, Winterhalter P, Kruse HP, Winkler S, Bub A, et al. Comparative biokinetics and metabolism of pure monomeric, dimeric, and polymeric flavan-3-ols: a randomized cross-over study in humans. Mol Nutr Food Res (2015) 59(4):610-21. doi:10.1002/mnfr.201400422

184. Massot-Cladera M, Pérez-Berezo T, Franch A, Castell M, Pérez-Cano FJ. Cocoa modulatory effect on rat faecal microbiota and colonic crosstalk. Arch Biochem Biophys (2012) 527(2):105-12. doi:10.1016/j.abb.2012.05.015

185. Magrone T, Jirillo E. The interplay between the gut immune system and microbiota in health and disease: nutraceutical intervention for restoring intestinal homeostasis. Curr Pharm Des (2013) 19(7):1329-42. doi:10.2174/ 138161213804805793

186. Vauzour D, Rodriguez-Mateos A, Corona G, Oruna-Concha MJ, Spencer JP. Polyphenols and human health: prevention of disease and mechanisms of action. Nutrients (2010) 2(11):1106-31. doi:10.3390/nu2111106

187. Kalaria RN. Cerebrovascular disease and mechanisms of cognitive impairment: evidence from clinicopathological studies in humans. Stroke (2012) 43(9):2526-34. doi:10.1161/STROKEAHA.112.655803
188. Chao MV. Neurotrophins and their receptors: a convergence point for many signalling pathways. Nat Rev Neurosci (2003) 4(4):299-309. doi:10.1038/ nrn1078

189. Garthwaite J. Concepts of neural nitric oxide-mediated transmission. Eur J Neurosci (2008) 27(11):2783-802. doi:10.1111/j.1460-9568.2008.06285.x

190. Cheng A, Wang S, Cai J, Rao MS, Mattson MP. Nitric oxide acts in a positive feedback loop with BDNF to regulate neural progenitor cell proliferation and differentiation in the mammalian brain. Dev Biol (2003) 258(2):319-33. doi:10.1016/S0012-1606(03)00120-9

191. Williams JA, Vincent SR, Reiner PB. Nitric oxide production in rat thalamus changes with behavioral state, local depolarization, and brainstem stimulation. J Neurosci (1997) 17(1):420-7.

192. Harder DR, Alkayed NJ, Lange AR, Gebremedhin D, Roman RJ. Functional hyperemia in the brain: hypothesis for astrocyte-derived vasodilator metabolites. Stroke (1998) 29(1):229-34. doi:10.1161/01.STR.29.1.229

193. Hollman $\mathrm{CH}$. The 4 th international conference on polyphenols and health. Nutr Bull (2010) 35(2):183-5. doi:10.1111/j.1467-3010.2010.01814.x

194. Kovacsova M, Barta A, Parohova J, Vrankova S, Pechanova O. Neuroprotective mechanisms of natural polyphenolic compounds. Act Nerv Super Red (2010) 52(3):181-6.

195. Parohova J, Vrankova S, Barta A, Kovacsova M, Bartko D, Pechanova O. The cross-talk of nuclear factor kappa B and nitric oxide in the brain. Act Nerv Super Red (2009) 51:123-6.

196. Pechanova O. Contribution of central nervous system to hypertension: role of angiotensin II and nitric oxide. Act Nerv Super Red (2010) 52(4):223-7.

197. Pechánová O, Rezzani R, Babál P, Bernátová I, Andriantsitohaina R. Beneficial effects of provinols: cardiovascular system and kidney. Physiol Res (2006) 55(Suppl 1):S17-30.

198. Jung J, $\mathrm{Na} \mathrm{C}$, Huh Y. Alterations in nitric oxide synthase in the aged CNS. Oxid Med Cell Longev (2012) 2012:718976. doi:10.1155/2012/718976

199. Susswein AJ, Katzoff A, Miller N, Hurwitz I. Nitric oxide and memory. Neuroscientist (2004) 10(2):153-62. doi:10.1177/1073858403261226

Conflict of Interest Statement: The authors declare that the research was conducted in the absence of any commercial or financial relationships that could be construed as a potential conflict of interest.

Copyright $\odot 2017$ Magrone, Russo and Jirillo. This is an open-access article distributed under the terms of the Creative Commons Attribution License (CC BY). The use, distribution or reproduction in other forums is permitted, provided the original author(s) or licensor are credited and that the original publication in this journal is cited, in accordance with accepted academic practice. No use, distribution or reproduction is permitted which does not comply with these terms. 